\title{
In Vitro Validation Studies For Adhesion Factor and Adhesion Efficiency of Probiotic Bacillus Licheniformis MCC 2514 and Bifidobacterium Breve NCIM 5671 on HT-29 Cell Lines
}

\section{Rohith HS}

CSIR-CFTRI: Central Food Technological Research Institute CSIR

Prakash Motiram Halami ( $\sim$ prakashalami@cftri.res.in )

CSIR-CFTRI https://orcid.org/0000-0002-0293-1891

\section{Original Paper}

Keywords: Bacillus, Bifidobacteria, Adhesion, Probiotics, Invasion, health benefits

Posted Date: February 16th, 2021

DOI: https://doi.org/10.21203/rs.3.rs-198009/v1

License: (c) (1) This work is licensed under a Creative Commons Attribution 4.0 International License. Read Full License

Version of Record: A version of this preprint was published at Archives of Microbiology on March 27th, 2021. See the published version at https://doi.org/10.1007/s00203-021-02257-y. 


\section{Abstract}

Probiotic bacterial adhesion to the epithelial cell is a composite process and in vivo adhesion studies can be strengthened with the improved in vitro models for preliminary screening of potentially adherent strains. With this rationale, the study aimed is the first report to demonstrate the colonizing efficiency of probiotic Bacillus licheniformis MCC 2514 in comparison to Bifidobacterium breve NCIM 5671on HT-29 cell line. B. licheniformis (54.28 $\pm 0.99 \%)$ and Bif. breve $(70.23 \pm 0.85 \%)$ adhered in a higher percentage on fibronectin and mucin, respectively. However, the adhesion was higher for $B$. licheniformis when compared to Bif. breve. In adhesion score, $B$. licheniformis obtained about $138.85 \pm 12.32$, whereas Bif. breve got the score of $43.05 \pm 9.12$. The same trend continued in the adhesion percentage study, where $B$. licheniformis adhered $75.5 \pm 5.2 \%$, higher than Bif. breve adhered $32.66 \pm 3.2 \%$. In invasion assay, both the bacteria significantly decreased the colonization of the pathogen Kocuria rhizophila ATCC 9341 about $97.32 \pm 0.81 \%$ in the competitive assay, $97.87 \pm 0.73 \%$ in exclusion assay and $82.19 \pm 2.51 \%$ in displacement assay. The cytotoxicity effects of the test bacterial strains against HT-29 cell line through MTT assay determined no viability loss in the treated cells. Therefore, the data obtained from the in vitro studies showed that both $B$. licheniformis and Bif. breve had shown significantly good invasion on pathogen and adhesion capacity on HT-29 cell line.

\section{Introduction}

Probiotics are 'live micro-organisms which when administered in adequate amounts confer a health benefit on the host' (Hill et al. 2014). Bacterial adherence to the host tissue and colonization has been the prominent step for bacterial infection (Ayala et al. 2017). The capability to adhere to the mucosal surface can be a reasonable advantage for thriving in humans' gastrointestinal tract (Bernet et al. 1994). In many probiotic bacterial strains, effective colonization can also be evaluated to adhere to the epithelium cell where the mucosal surface has been suggested to be an important trait for activity (Duary et al. 2011). Studies have suggested a wide range of adhesion factors responsible for the adhesion of bacteria to the human gut system. The major common bacterial adhesion factor is fibronectin-binding protein (Romberger 1997), mucus binding protein (Johansson et al. 2008), extracellular appendages such as flagella, pili and fimbriae (Erdem et al. 2007), sortase dependent proteins (Marraffini et al. 2006), lactobacilli surface layers proteins (S-layers) (Palva 2005), multifunctional Lactobacillus mucus adhesion protein (Tassell and Miller 2011), lectin-like mucus adhesins (Juge 2012), Numerous human enteric pathogens attach to the human histo blood group antigens (HBGAs) demonstrated on the gut mucosa, such as Helicobacter pylori, Norwalk virus and Campylobacter jejuni (Lindell et al. 2008; Magalhães et al. 2010). The probiotic micro-organisms, which are used as starter cultures in different food products, adhere to intestinal epithelium cells and play a crucial part in the host immunomodulation process(Neish 2009; Swain et al. 2014).

Even after being beneficial bacteria, Bacillus spp. never gained much importance because of some toxic and pathogenic family members such as $B$. cereus, $B$. weihenstephanensis, $B$. anthracis, and $B$. thuringiensis (Elshaghabee et al., 2017). Most of the studies on Bacillus concentrated only on industrial 
usage and very few on food products where the exposure to probiotic aspects of Bacillus are not well studied. Understanding the probiotic attribute of the Bacillus licheniformis would lead to new opportunities in the field of Bacillus utilization as probiotic bacteria. A combination of facultative anaerobic Bacillus licheniformis and anaerobic Bifidobacterium breve can be the better competitor for the gut system's pathogen. Bifidobacteria inhabits in the gut system in the very early stages of life, making a permanent member of the GIT and bacilli a non-member. The introduction of these two bacteria, which colonize in different parts of the colon, can affect the colonizing factor of the pathogen.

B. licheniformis MCC 2514 is a native isolate obtained from goat milk, which has exhibited major probiotic attributes such as the ability to survive under gastric conditions like low $\mathrm{pH}$, pepsin; intestinal conditions such as high $\mathrm{pH}$; in the presence of trypsin and pancreatin. It also exhibited antioxidant, antimicrobial, cell hydrophobicity and auto-aggregation property (Shobharani and Halami 2014). Bif. Breve is a native isolate obtained from an infant fecal sample that has exhibited safety and functional attributes such as phytase activity, milk fermentation ability, antioxidant activity and antimicrobial activity (Achi and Halami 2019). In the gastrointestinal tract, the epithelium is being protected using many mechanisms from pathogen bacteria. One of the main mechanisms in reducing pathogenic infection is competition of micro-organism for adhesion sites with antimicrobial components produced by probiotic bacteria or deploying probiotic bacteria itself against pathogen bacteria(Ouwehand and Vesterlund 2003; Baccigalupi et al. 2005). This study was carried out to understand the binding and adhesion efficiency of very less studied Bacillus spp. as a co-culture with well-studied bifidobacteria under in vitro condition also in addition comparative evaluation of the Bacillus licheniformis and Bifidobacterium breve as single culture and as a co-culture against the foodborne pathogen Kocuria rhizophila, factors affecting adhesion, bacterial adhesion, inhibition studies and cytotoxicity study was assessed.

\section{Materials And Methods 2.1 Materials}

McCoy's medium, phosphate buffer saline, trypsin-EDTA solution, T25 cell culture plates, T75 cell culture plates, de Man, Rogosa and Sharpe (MRS) agar, brain heart infusion broth, trypton-yeast broth, fetal bovine serum (Himedia, Mumbai, India), $5 \mathrm{mg}$ streptomycin and 5000 units penicillin per $\mathrm{ml}$, DMSO, Lcystine $\mathrm{HCl}$, Giemsa stain, mucin and fibronectin (Sigma, Bangalore, India) 6 well plates (Corning, India), 12 well plates (Eppendroff, India), were procured for experimental studies until otherwise mentioned.

\subsection{Bacterial strains and culture conditions}

Bacillus licheniformis MCC 2514 isolated from goat milk (Shobharani and Halami 2014), a fecal isolate of Bifidobacterium breve NCIM 5671 (Achi and Halami 2019) and Kocuria rhizophila ATCC 9341 were used in the study. Potential probiotic cultures Bacillus licheniformis and Bifidobacterium breve are native laboratory isolates used to screen the adherence potential against cancerous epithelium HT-29 cell lines, which was procured from National Centre for Cell Sciences (NCCS), Pune, India. B. licheniformis were 
cultured in optimized trypton-yeast media, Bif. breve was grown in MRS medium with $0.05 \% \mathrm{~L}$-cystine $\mathrm{HCl}$ and K. rhizophila was cultured in BHI (Brain Heart Infusion) medium. B. licheniformis and K. rhizophila were grown at $37^{\circ} \mathrm{C}$ for about $18 \mathrm{~h}$ in a shaker incubator at $150 \mathrm{rpm}$ and Bif. breve was incubated on $\mathrm{CO}_{2}$ incubator at $37^{\circ} \mathrm{C}$ for $24 \mathrm{~h}$. In the entire study, B. licheniformis and Bif. breve was used as an individual culture and as co-cultures.

\subsection{Adhesion to mucin and fibronectin}

The ability of $B$. licheniformis and Bif. breve to bind fibronectin and mucin was evaluated as described by Roos and Jonsson (Roos and Jonsson 2002; Archer and Halami 2015). Briefly, the 96 well microtiter plates were coated with fibronectin $(50 \mu \mathrm{g} / \mathrm{mL})$ and $150 \mu \mathrm{l} /$ well of mucin $(100 \mu \mathrm{g} / \mathrm{ml})$ dissolved in $50 \mathrm{mM}$ $\mathrm{Na}_{2} \mathrm{CO}_{3}$ buffer with a $\mathrm{pH}$ of 9.7 . The 96 well plates were incubated overnight at $4^{\circ} \mathrm{C}$ with minimum shaking and later blocked with phosphate-buffered saline (PBS) of $0.2 \mathrm{~mL}$ supplemented with $1 \%$ Tween20 for one $h$ and it was thoroughly washed with PBST (0.05\% Tween 20 with PBS). Overnight grown bacterial cultures were washed using PBST, diluted to the OD600 of 1.0 in the same buffer and 150 $\mu \mathrm{L}$ was added to the wells and incubated at $37^{\circ} \mathrm{C}$ for one $\mathrm{h}$. All the wells were thoroughly washed with PBST and cell adherence was witnessed under the inverted microscope. Besides, to remove the adhered bacteria, $0.2 \mathrm{~mL}$ of Triton X-100 (0.5\%) was used and incubated at $37^{\circ} \mathrm{C}$ for two h. From every well, 100 $\mu \mathrm{L}$ of cell suspension was diluted and plated in respective medium and CFU count was observed.

\subsection{Maintenance of HT-29 Cell lines}

The HT-29 Epithelium cells were grown in McCoy's medium with $10 \%$ (v/v) of heat-inactivated $\left(56^{\circ} \mathrm{C}, 30\right.$ mins) fetal bovine serum, $5 \mathrm{mg}$ streptomycin and $5000 \mathrm{U}$ penicillin $/ \mathrm{ml}$ in $25 \mathrm{~cm}^{2}$ culture flask at $37^{\circ} \mathrm{C}$ in $5 \% \mathrm{CO}_{2}$. The incubated cells were fed with fresh medium every alternate day. After cells reaching confluency around $80 \%$, the cells were collected by incubating adhered cells with $0.25 \%$ Trypsin-EDTA solution at $37^{\circ} \mathrm{C}$. The cells were centrifuged (1200 rpm, 2 mins at room condition) and the cells were resuspended in McCoy's medium. Before incubating, the cells were counted using a hemocytometer (Rohem, India) and introduced into respective assay plates. For six-well plates, 3 x $10^{5}$ cells/well, for 12 well plates $7.5 \times 10^{4}$ cells / well and T25 flask $1 \times 10^{6}$ cells / well were added as described earlier by Gagnon et al. 2013.

\subsection{Binding efficiency on HT-29 cell line}

Adhesion assay on HT-29 was carried out with the previously described procedure with slight changes (Duary et al., 2011). Adhesion of the B. licheniformis and Bif. breve cultures to the HT-29 cell line were measured. The cell suspension with $3 \times 10^{5}$ cells added in $3 \mathrm{ml}$ McCoy's medium was transferred to each well into six-well adherent culture plates. The medium was replaced every alternate day. When these cells reached a confluency of $80 \%$, the medium was replaced every day repeatedly for about $15-20$ days. The exhausted medium was decanted three $\mathrm{h}$ prior to the adhesion assay and cells were introduced with McCoy's medium without antibiotics and incubated at $37^{\circ} \mathrm{C}$ for three $\mathrm{h}$ in $5 \% \mathrm{CO}_{2}$. After the incubation period, cells were thoroughly washed with $3 \mathrm{ml}$ phosphate-buffered saline (PBS) twice. The $B$. 
licheniformis and Bif. breve (at $1 \times 10^{8} \mathrm{CFU} / \mathrm{ml}$ ) cells were added to $1.0 \mathrm{ml}$ McCoy's medium (without antibiotics and FBS) and introduced into different wells. These treated plates were incubated at $37^{\circ} \mathrm{C}$ for four $\mathrm{h}$ in $5 \% \mathrm{CO}_{2}$. The monolayers were washed five times thoroughly using sterile PBS.

\subsection{Adhesion score, adhesion percentage and SEM analysis}

By following the procedure described in Sect. 2.5, adhesion study experiments were carried out, $3 \mathrm{ml}$ of methanol was introduced into each well containing the cells and incubated for $10 \mathrm{~min}$ at room condition. Methanol was aspirated completely and cells were stained using 1:20 diluted Giemsa for 90 min at ambient condition. The wells which were fixed are washed using pure ethanol to take out the unwanted stain. The air-dried plates were examined under 100x magnification (BX 5, Olympus, Japan). The bacteria were counted in 20 random microscopic fields and were labeled into different groups according to their counts, such as strongly adhesive ( $>100$ bacteria/field), adhesive ( $41-100$ bacteria/field) and nonadhesive ( $\leq 40$ bacteria/field). Continuing the adhesion assay procedure, the cell monolayer from the treated plate was separated using trypsinization. A $0.25 \%$ trypsin-EDTA solution was introduced into each well of six-well plates and incubated for $15 \mathrm{~min}$ at room condition. The detached cells were gently homogenized to make a uniform suspension. The cells were then plated on Tryptone-yeast agar for $B$. licheniformis and plated on MRS agar for Bif. breve using serial dilution. After the incubation at $37^{\circ} \mathrm{C}$ for 24-48 $\mathrm{h}$, colonies were counted $\left(\mathrm{B}_{1} \mathrm{CFU} / \mathrm{ml}\right)$. Bacterial cells initially added to each well of six-well plates were also counted $\left(\mathrm{B}_{0} \mathrm{CFU} / \mathrm{ml}\right)$.

The adhesion percentage was calculated using the below formula:

$\%$ adhesion $=\left(B_{1} / B_{0}\right) * 100$

For scanning electron Microscopy observation, the HT-29 cells were grown and maintained on glass coverslips until the monolayer is achieved. Later cells were fixed using $2.5 \%$ glutaraldehyde solution and incubated at $4{ }^{\circ} \mathrm{C}$ for overnight. The ascending gradation of alcohol dehydration (30\%, 50\%, $70 \%, 90 \%$, $95 \%$ and $100 \%$ ) was carried on coverslips and finally, air-dried coverslips were subjected to gold plating and observed under SEM (LEO 435 VP, Carl Zeiss, Cambridge, UK) (Manjulata et al. 2018).

\subsection{Inhibition of Kocuria rhizophila from colonizing HT-29 cell line}

Inhibition of foodborne pathogen Kocuria rhizophila by B. licheniformis and Bif. breve from colonizing on HT-29 cell line was measured by the following assays as described before with slight modifications (Kumar et al. 2011).

For competition assay, both $B$. licheniformis and Bif. breve $\left(1 \times 10^{8} \mathrm{CFU} / \mathrm{ml}\right)$ and $K$. rhizophila $\left(1 \times 10^{8}\right.$ $\mathrm{CFU} / \mathrm{ml}$ ) added in one $\mathrm{ml} \mathrm{Mc}$ Coy's medium (without antibiotics and FBS) and suspended into HT-29 cells and incubated at $37^{\circ} \mathrm{C}$ for $90 \mathrm{~min}$ in $5 \% \mathrm{CO}_{2}$ condition. After the incubation time, non-adhered bacterial cells were detached by washing the wells thoroughly with PBS trice and adhered bacterial cells were 
obtained by treating with $0.25 \%$ trypsin at $37^{\circ} \mathrm{C}$ for $10 \mathrm{~min}$. The obtained bacterial cells were plated in respective medium (Optimized tryptone-yeast medium for $B$. lichenifomis, MRS agar for Bif. breve and $\mathrm{BHI}$ agar for $K$. rhizophila) for their culturing. The total bacterial count was denoted in log $\mathrm{CFU} / \mathrm{ml}$. Control or un-treated wells were maintained for both B. lichenifomis and Bif. breve and K. rhizophila, and they were standard for all of the assays. For exclusion assay, B. lichenifomis and Bif. breve $\left(1 \times 10^{8} \mathrm{CFU} / \mathrm{ml}\right)$ cells were introduced to the $\mathrm{HT}-29$ cell line and incubated at $37^{\circ} \mathrm{C}$ for $90 \mathrm{~min}$ in $5 \% \mathrm{CO}_{2}$. Weakly attached cells were removed by thoroughly washing with PBS. After washing, $K$. rhizophila $\left(1 \times 10^{8} \mathrm{CFU} / \mathrm{ml}\right)$ cells were added to the HT-29 cells, which are already colonized by B. lichenifomis and Bif. Breve was allowed for incubation at $37^{\circ} \mathrm{C}$. At the end of the incubation, weakly attached cells were detached using PBS wash thoroughly, and bacterial cells adhered to were obtained using trypsinization and CFU/ml. For displacement assay, initially $K$. rhizophila in the concentration of $1 \times 10^{8} \mathrm{CFU} / \mathrm{ml}$ cells were introduced on $\mathrm{HT}-29$ cells and incubated at $37^{\circ} \mathrm{C}$ for $90 \mathrm{~min}$ in $5 \% \mathrm{CO}_{2}$.. Weakly attached cells were detached by washing thrice with PBS wash. After the wash, B. lichenifomis and Bif. breve $\left(1 \times 10^{8} \mathrm{CFU} / \mathrm{ml}\right)$ were added to HT-29 cells which are already adhered with $K$. rhizophila. The treatment which is mentioned in the exclusion assay was followed. All three assays were carried out in triplicates, and results were interpreted statistically. SEM analysis was determined with glutaraldehyde and alcohol dehydration in ascending gradation (Manjulata et al., 2018).

\subsection{Cytotoxicity studies using MTT assay and confocal microscope}

To study the cytotoxic effects of bacteria on the epithelium cell line, MTT assay and confocal microscopy were performed (Xi et al. 2009). The B. licheniformis and Bif. breve cultures to the HT-29 cell line were measured. The HT-29 cell suspension with $4 \times 10^{4}$ cells $/ \mathrm{ml}$ cell concentration prepared in $0.1 \mathrm{ml}$ complete McCoy's medium and it was transferred to the individual well of 96-well culture plates. These plates were incubated at $37^{\circ} \mathrm{C}$ for $48 \mathrm{~h}$ in $5 \% \mathrm{CO}_{2}$ for better adhesion and growth. After the incubation, the 96 wells were thoroughly washed using PBS and cells were fed with McCoy's medium lacking antibiotics of $1 \times 10^{8} \mathrm{CFU} / \mathrm{ml}$ of both $B$. licheniformis and Bif. breve and were incubated at $37^{\circ} \mathrm{C}$ for four $\mathrm{h}$. Later, the incubated cells were washed 3 to 5 times thoroughly using PBS to remove bacteria from the wells and a $10 \mu$ of MTT reagent was added to the cell containing fresh Mc Coy's medium and incubated at $37^{\circ} \mathrm{C}$ for four $\mathrm{h}$ in $5 \% \mathrm{CO}_{2}$. The medium was aspirated from the well and $100 \mu \mathrm{l}$ of DMSO reagent was added and incubated at $37^{\circ} \mathrm{C}$ for 30 mins. Reading taken at $570 \mathrm{~nm}$ and the percentage of the viability was calculated using the below equation

$\%$ Viability $=Q_{1} / Q_{0} \times 100 .\left(Q_{0}=\right.$ control reading, $Q_{1}=$ treated reading $)$

For confirmation of cytotoxicity on HT 29 cell line, confocal microscopy for the B. licheniformis and Bif. breve cultures were performed. The HT-29 cell with the concentration of $3 \times 10^{5}$ cells was prepared in 3 $\mathrm{ml}$ McCoy's medium and it was added to every individual well of 12-well culture plates. It was incubated at $37^{\circ} \mathrm{C}$ for $48 \mathrm{~h}$ for better adhesion and growth. After the incubation, wells were thoroughly washed using 
sterile PBS and cells were fed with McCoy's medium lacking antibiotics with the bacterial concentration of $1 \times 10^{8}$ of both $B$. licheniformis and Bif. breve and incubated at $37^{\circ} \mathrm{C}$ for four $\mathrm{h}$. The incubated cells were then washed with sterile PBS several times to remove the bacterial cells and treated with $0.5 \mathrm{ml}$ of absolute chilled alcohol and incubated for two $\mathrm{h}$ at $-20^{\circ} \mathrm{C}$. After incubation, the cells were suspended in $0.5 \mathrm{ml}$ of PBS to avoid drying of the cell until the microscopy observation. Fluorescence dyes such as Acridine orange and ethidium bromide $(\mathrm{EtBr})$ dye were added 5 mins before the observation under the confocal microscope (LSM 700, Carl Zeiss, Germany).

\subsection{Statistical analysis}

All the data was subjected to statistical analysis was performed using one-way ANOVA using the Graph Pad Prism 7. All data are denoted as mean \pm standard deviation (SD). In all the experiments, significance was set at $P<0.05$.

\section{Results}

\subsection{Binding efficiency of B. licheniformis and B. breve to mucin and fibronectin}

The adhesion factors play a critical role in the adhesion process in bacteria on epithelium cells in GIT. The adhesion efficiency in B. licheniformis and Bif. breve using mucin and fibronectin was analyzed in this experiment. On adhesion to mucin, both the bacteria have shown better adhesion of $70.23 \pm 0.85 \%$ for Bif. breve and $65.01 \pm 0.11 \%$ for $B$. licheniformis. In adhesion to fibronectin, $B$. licheniformis had a higher adhesion percentage of $54.28 \pm 0.99$ compared to Bif. breve of $39.66 \pm 0.74 \%$, indicating both the bacteria had better adhesion on both mucin and fibronectin. The all values are the mean $\pm \operatorname{SD}(n=3)$.

\subsection{Adhesion of probiotic bacteria on HT-29 cells line using score and percentage method}

Adhesion efficiency can be calculated on the number of bacteria adhered to GIT. The numbers were estimated using the score and percentage method. Considering scoring method for adhesion analysis, both $B$. licheniformis and Bif. breve adhered to HT-29 cell lines through different points. In this evaluation, $B$. licheniformis adhesion score with $138.85 \pm 12.32$ adhere significantly strong when compared to Bif. breve with a score of $43.05 \pm 9.12$. Inoculation of $B$. licheniformis and Bif. breve as a co-culture did not show much deviation. $B$. licheniformis has the same adhesion score $135.43 \pm 8.49$, significantly higher adhesion on the comparison with Bif. breve $34.04 \pm 8.81$ (Fig. 1). The microscopic observation gives an identity proof for the adhesion of bacteria in Fig. 1.

Adhesion percentage was calculated by plating on MRS agar for Bif. breve and TY agar for $B$. licheniformis (Table 1). Adhesion of $B$. licheniformis was significantly high of $75.5 \pm 5.2 \%$ in comparison to the adhesion of Bif. breve $32.6 \pm 3.2 \%$ which was moderate. It was observed that under co-culturing of the test bacteria, the percentage of Bif. breve was decreased to $24.5 \pm 1.1 \%$ and B. licheniformis was 75.5 
$\pm 2.6 \%$ with significant changes. The results indicated that $B$. licheniformis had better adhesion when compared to Bif. breve (Fig. 1). The adhesion efficiency of test bacterial results was documented using a scanning electron microscope for better understanding. Adhesion of the bacteria in combination adhered together can be observed in the same field circled in Fig. 1 .

Table 1

Adhesion percentage of $B$. licheniformis and Bif. Breve in $\mathrm{CFU} / \mathrm{ml}$.

\section{Group}

B. licheniformis

Control

B. licheniformis

After adhesion

B. licheniformis in combination

After adhesion

Bif. breve

Control

Bif. breve

After adhesion

Bif. breve

in combination

After adhesion

The value presented is the mean \pm SD $(n=4)$ of adhesion of $B$. licheniformis \& Bif. breve on HT-29 cell lines

\subsection{Invasion assays of probiotic bacteria on K. rhizophila}

The inhibition efficiency of probiotic bacteria against pathogen $K$. rhizophila was performed using three assays. The control log CFU/ml recorded was $7.62 \pm 0.021$ for $B$. licheniformis, $7.50 \pm 0.036$ for Bif. breve and $7.73 \pm 0.20$ for $K$. rhizophila. The $K$. rhizophila was treated with both test cultures individually as well as a co-culture (Tables $2 \& 3$ ). Untreated control remained constant for all three experimental assays. The results of the assay were documented as a scanning electron microscopic observation (Fig. 2). 
Table 2

Invasion assay against $K$. rhizophila using probiotic $B$. licheniformis and Bif. Breve

\begin{tabular}{|c|c|c|c|c|}
\hline & K. rhizophila & $\begin{array}{l}\text { Initial log CFU/ml of } \\
\text { K. rhizophila }\end{array}$ & $\begin{array}{l}\text { Final log } \\
\text { CFU/ml of } \\
\text { K. } \\
\text { rhizophila }\end{array}$ & $\begin{array}{l}\text { Reduction of } \\
\text { Adhesion in \% } \\
\text { K. hizophila }\end{array}$ \\
\hline \multirow[t]{3}{*}{$\begin{array}{l}\text { Competition } \\
\text { assay }\end{array}$} & $\begin{array}{l}\text { Against } B \text {. } \\
\text { licheniformis }\end{array}$ & \multirow[t]{3}{*}{$7.73 \pm 0.20$} & $7.02 \pm 0.02$ & $89.44 \pm 2.02$ \\
\hline & Against Bif. breve & & $7.16 \pm 0.08$ & $75.16 \pm 4.58$ \\
\hline & $\begin{array}{l}\text { Against } B \text {. } \\
\text { licheniformis \& Bif. } \\
\text { breve }\end{array}$ & & $6.20 \pm 0.17$ & $97.32 \pm 0.81$ \\
\hline \multirow[t]{3}{*}{$\begin{array}{l}\text { Exclusion } \\
\text { assay }\end{array}$} & $\begin{array}{l}\text { Against } B \text {. } \\
\text { licheniformis }\end{array}$ & \multirow[t]{3}{*}{$7.73 \pm 0.20$} & $6.93 \pm 0.16$ & $85.58 \pm 3.77$ \\
\hline & Against Bif. breve & & $7.160 \pm 0.10$ & $76.13 \pm 3.20$ \\
\hline & $\begin{array}{l}\text { Against } B \text {. } \\
\text { licheniformis \& Bif. } \\
\text { breve }\end{array}$ & & $6.10 \pm 0.17$ & $97.87 \pm 0.73$ \\
\hline \multirow[t]{3}{*}{$\begin{array}{l}\text { Displacement } \\
\text { assay }\end{array}$} & $\begin{array}{l}\text { Against } B \text {. } \\
\text { licheniformis }\end{array}$ & \multirow[t]{3}{*}{$7.73 \pm 0.20$} & $7.2 \pm 0.06$ & $71.33 \pm 5.18$ \\
\hline & Against Bif. breve & & $7.25 \pm 0.09$ & $70.61 \pm 5.07$ \\
\hline & $\begin{array}{l}\text { Against } B \text {. } \\
\text { licheniformis \& Bif. } \\
\text { breve }\end{array}$ & & $7.04 \pm 0.03$ & $82.19 \pm 2.51$ \\
\hline
\end{tabular}


Table 3

Invasion assay against $K$. rhizophila using probiotic B. licheniformis and Bif. Breve (plating CFU/ml)

\begin{tabular}{|c|c|c|c|}
\hline & K. thizophila & $\begin{array}{l}\text { Initial CFU/ml of } K \text {. } \\
\text { rhizophila }\end{array}$ & $\begin{array}{l}\text { Final CFU/ml } \\
\text { of } \\
\text { K. rhizophila }\end{array}$ \\
\hline \multirow[t]{3}{*}{$\begin{array}{l}\text { Competition } \\
\text { assay }\end{array}$} & Against $B$. licheniformis & $6.23 \pm 0.41 \times 10^{7}$ & $\begin{array}{l}1.06 \pm 0.04 \\
x 10^{7}\end{array}$ \\
\hline & Against Bif. breve & & $\begin{array}{l}1.56 \pm 0.38 \\
\times 10^{7}\end{array}$ \\
\hline & $\begin{array}{l}\text { Against } B \text {. licheniformis \& Bif. } \\
\text { breve }\end{array}$ & & $\begin{array}{l}1.66 \pm 0.47 \\
\times 10^{6}\end{array}$ \\
\hline \multirow[t]{3}{*}{ Exclusion assay } & Against $B$. licheniformis & $6.23 \pm 0.41 \times 10^{7}$ & $9 \pm 0.29 \times 10^{6}$ \\
\hline & Against Bif. breve & & $\begin{array}{l}1.50 \pm 0.29 \\
\times 10^{7}\end{array}$ \\
\hline & $\begin{array}{l}\text { Against } B \text {. licheniformis \& Bif. } \\
\text { breve }\end{array}$ & & $\begin{array}{l}1.33 \pm 0.47 \\
x 10^{6}\end{array}$ \\
\hline \multirow[t]{3}{*}{$\begin{array}{l}\text { Displacement } \\
\text { assay }\end{array}$} & Against $B$. licheniformis & $6.23 \pm 0.41 \times 10^{7}$ & $\begin{array}{l}1.76 \pm 0.20 \\
\times 10^{7}\end{array}$ \\
\hline & Against Bif. breve & & $\begin{array}{l}1.83 \pm 0.33 \\
\times 10^{7}\end{array}$ \\
\hline & $\begin{array}{l}\text { Against } B \text {. licheniformis \& Bif. } \\
\text { breve }\end{array}$ & & $\begin{array}{l}1.10 \pm 0.08 \\
\times 10^{7}\end{array}$ \\
\hline
\end{tabular}

Invasion assay using simultaneous colonization (Competition assay), the count of $K$. rhizophila when treated with $B$. licheniformis the count of $K$. rhizophila was decreased to $7.02 \pm 0.02 \mathrm{log} C F U / \mathrm{ml}(10.56 \pm$ $2.02 \%)$ and with Bif. breve the count of $K$. rhizophila decreased to $7.16 \pm 0.08 \mathrm{CFU} / \mathrm{ml}(24.84 \pm 4.58 \%)$. When both B. licheniformis and Bif. Breve used as co-culture, the pathogen reduction was shown to be $6.20 \pm 0.17 \mathrm{CFU} / \mathrm{ml}(2.68 \pm 0.81 \%)$, which indicates that test culture has decreased the count of pathogen significantly $(\mathrm{p}<0.05)$. On exclusion assay wherein the cells of $K$. rhizophila are treated with $B$. licheniformis, the count of $K$. rhizophila was decreased to $6.93 \pm 0.16 \log \mathrm{CFU} / \mathrm{ml}(14.42 \pm 3.77 \%)$ and when treated with Bif. breve it decreased to $7.16 \pm 0.10 \mathrm{CFU} / \mathrm{ml}(23.87 \pm 3.20 \%)$. Co-culturing of both $B$. licheniformis and Bif. Breve, it reduced to $6.10 \pm 0.17 \mathrm{CFU} / \mathrm{ml}(2.13 \pm 0.73 \%)$, indicating that the test culture has decreased the pathogen significantly $(p<0.05)$.

During the post-colonization of probiotics over $K$. rhizophila (displacement assay), $K$. rhizophila was treated with $B$. licheniformis and the count of $K$. rhizophila was decreased to $7.2 \pm 0.06 \mathrm{log} \mathrm{CFU} / \mathrm{ml}$ 
$(28.67 \pm 5.18 \%)$ when treated with Bif. breve decreased to $7.25 \pm 0.09 \mathrm{CFU} / \mathrm{ml}(29.39 \pm 5.07 \%)$. In the coculturing of both B. licheniformis and Bif. Breve, it reduced to $7.04 \pm 0.03 \mathrm{CFU} / \mathrm{ml}(17.81 \pm 2.51 \%)$. The results indicated that test culture had decreased the pathogen significantly $(p<0.05)$ (Fig. 2). The invasion of probiotic bacteria on pathogen can be seen where the cell count of the $K$. rhizophila is very low when treated with $B$. licheniformis and Bif. breve. Co-culturing of bacteria incubated together can be seen in the highlighted circle in Fig. 2. Overall, the simultaneous and pre inoculation of probiotic bacteria has inhibited the pathogen.

\subsection{Viability count of HT-29 on the treatment of probiotic bacteria}

The viability of the epithelium cells (HT-29) on the treatment of B. licheniformis and Bif. breve was checked using MTT assay. Viability count did not show much deviation on the treatment either with $B$. licheniformis or Bif. breve alone or in combination. Viability count did not show much deviation with the treatment of test bacteria as a co-culture compared to the treatment of bacteria as an individual culture. At $1 \times 10^{8}$ cell concentration, the Percentage of viability was found as $93.53 \pm 0.53 \%, 94.78 \pm 2.27 \%$ and $98.80 \pm 0.97 \%$ on the treatment of $B$. licheniformis, Bif. breve and in combination, respectively. The viability of the cell line was documented using confocal microscopic observation Fig. 3.

\section{Discussion}

In vivo animal models are the chosen approach for proving safety and probiotic bacterial efficiency towards effective colonization in the gut. Traditional safety valuation methods depending on toxicological screening in animals might not be valid in the circumstance of foods in many cases (Fao et al. 2002). No particular guiding principle is present for evaluating probiotics, but studies such as a repeated administration of chronic toxicity and acute toxicity assessment have been suggested (Ishibashi and Yamazaki 2001). Some in vitro studies have been carried out for estimating various characters of potential probiotic bacteria. The bile content and tolerance of the low $\mathrm{pH}$ in the upper part of the gut system are the first line of challenge and colonizing in the lower part of the intestine is the second and most important aspect. Adhesion to the intestine is the well-preferred mechanism observed in probiotic bacteria for their establishment and demonstrates probiotic effect (Lee and Salminen 1995).

Concerning microbiota, the mucus has a dual role where it provides a primary adhesion site and matrix where bacteria can multiply and increase. It also protects from undesired contact with pathogenic bacteria (Van Klinken et al. 1995). Few strains of Lactobacillus fermentum have shown good adhesion to mucin and fibronectin (Archer and Halami 2015). Certain strains of $B$. cereus have shown great adhesion on mucin and fibronectin (Sánchez et al. 2009) and B. licheniformis had shown higher mucin binding capacity in the study conducted earlier. An earlier study has shown greater adhesion of spores to hydrophilic and hydrophobic surfaces than vegetative cells (Shobharani and Halami 2014). On similar lines to the existing reports, the present study on both $B$. licheniformis and Bif. breve has shown a greater binding capacity to mucus membrane. Bif. breve adhered in higher percentage in comparison to $B$. 
licheniformis. In the fibronectin study, B. licheniformis has shown higher adhesion percentage when compared to Bif. breve. Depending on the hydrophobicity characteristic, the Bacillus spores can also adhere to a different kind of surface, such as stainless steel (Peng et al. 2001). B. licheniformis has exhibited good cell hydrophobicity toward xylene, toluene, and hexadecane under in vitro conditions stimulated with solvents (Shobharani and Halami 2014).

In this investigation, the adhesion capacity of the probiotic bacteria was evaluated using adhesion score and adhesion percentage. On proportional valuation based on adhesion score, B. licheniformis showed significantly strong adhesion compared to Bif. breve. Both the bacteria were incubated together for compatibility and to check the probiotic effect in combination. No much deviation was found concerning B. licheniformis and a slight decrease was observed in the case of Bif. breve. In another study reported earlier, maximum adherence was found by Lactobacillus acidophilus LA 1 strain of $124 \pm 13$ (Bernet et al. 1994) and by Lactobacillus paraplantarum 128 (Manjulata et al. 2018), which gives a similar result to that of $B$. licheniformis. Other studies with Lactobacillus sp. have displayed a lesser adhesion score of 38-55 (Jacobsen et al. 1999) compared to B. licheniformis but higher than Bif. breve. The adhesion score of Bif. breve aligned with earlier studies reported with an adhesion score of $30 \pm 2$ on HT-29 cell line (Bernet et al. 1993) and Bif. longum has been reported with a little higher adhesion score (Del Re et al. 2000). The spore-producing $B$. licheniformis had significantly higher adhesion when compared to Bif. breve. When both the cultures were inoculated in combination together, the result was a similar but slight decrease in Bif. breve cell count was noticed. Other studies suggest that $B$. tequilensis has shown less adhesion percentage on human colon carcinoma epithelial cells such as HCT-116 (Rani et al. 2016) and B. subtilis on HT29-16E, Caco-2 and HEp-2 cell line. Bif. bifidum and Bif. longum have demonstrated higher adhesion percentage on Caco-2 cell line in previous studies (Achi and Halami 2019).

Adhesion of pathogens to the epithelium is an important step as it permits the discharge of enzymes and toxins, starting necrotic processes directly to the target cell and assisting the invasion (Bernet et al. 1994). By deploying the probiotic bacteria and the production of antimicrobial component and other organic compounds from these bacteria, using microbial pathogens, the decrease in pathogenic contaminations through competition for adhesion sites can cause greater damage for pathogen colonization (Kumar et al. 2011). The inhibitory study was carried out to understand the efficiency of B. licheniformis and Bif. breve against colonizing of foodborne pathogen K. rhizophila. In invasion assay, the adhesion of $K$. rhizophila was out numbered on the introduction of probiotic $B$. licheniformis and Bif. Breve. In all the three assay's, the reduction of $K$. rhizophila was in the range of $70-97 \%$. Scanning electron microscope analysis confirmed the above-mentioned effect. In similar studies, Lactobacillus plantarum has outnumbered the pathogen Vibrio parahaemolyticus in all assay types (Kumar et al. 2011). In another study, adhesion of Salmonella enterica was decreased by Lactobacillus paracasei by fourfold in competitive and in exclusion experiment about seven-fold (Bernet et al. 1994)

Previous studies showed the $B$. subtilis and Bif. indicus seemed to show no indication of any toxicity(Hong et al. 2008). Azimirad et al. (2017) has demonstrated the non-toxicity of $B$. coagulans and B. subtilis on HT29 cell lines(Azimirad et al. 2017). No cytotoxicity effect was found by using 
exopolysaccharides produced Bif. longum on HT-29 (Inturri et al. 2017). In this study, our data suggested that both the bacteria, i.e., $B$. licheniformis and Bif. breve did not show any cytotoxic effect and no viability of HT-29 cell was affected when used as lone culture and combination. HT- cell line29 is the most commonly used human intestinal cell line displaying the physiological and morphological characteristics of normal human enterocytes, which has been used to explain the mechanism mediating bacterial adhesion (Kerneis et al. 1991; Bernet et al. 1994). The obtained results can be correlated to the human gut environment. The in vitro data can be used as a reference for the in vivo studies. The adhesion and invasion efficiency displayed by the $B$. licheniformis and Bif. breve on HT-29 cells can be expected during the in vivo studies. However, evaluating the results through in vivo or clinical trials will enhance the utilization of these bacterial strains in combination with food product development, nutraceutical or any other human beneficial usage.

\section{Conclusion}

The potential probiotic $B$. licheniformis has shown very good adhesion capacity on the gastrointestinal tract compared to well-studied Bif. breve which was indicated by the HT-29 cell line. The adhesion factor such as fibronectin-binding protein in B. licheniformis and mucin binding protein in Bif. breve was dominated and demonstrated the most influenced factor which is affecting the adhesion. $B$. licheniformis had displayed higher adhesion potential when compared to Bif. breve. Both the bacteria have shown good invasion ability against the $K$. rhizophila. During simultaneous colonization and precolonization, K. rhizophila has reduced drastically and in post-colonization, $K$. rhizophila has shown better colonization compared to the other two assays. Both the bacteria did not show any toxicity on the HT-29 cell line, which proved that both are efficient probiotic bacteria regarding colonization in the gut system. The spore-forming bacteria always have an advantage in adhesion when compared to the nonspore bacteria. Hence, the $B$. licheniformis has shown greater adhesion efficiency when compare to Bif. breve. Overall it is concluded that both under in vitro conditions $B$. licheniformis and Bif. breve has shown better adhesion and invasion ability and a better contender to colonize and gastrointestinal tract. The outcome of In vitro studies will be additional validation before performing the in vivo studies of probiotic and probiotic food formulation.

\section{Declarations}

\section{Funding}

The research work carried under DST funded project (sanction no. EEQ/2016/000310), Department of Science and Technology, New Delhi.

\section{Conflict of interest}

The authors have no conflict of interest.

\section{Ethics approval}


Not applicable

\section{Consent to participate}

Not applicable

\section{Consent for publication}

Not applicable

\section{Authors' contributions}

All authors contributed to the study conception and design. Material preparation, data collection and analysis were performed by Rohith HS. Rohith HS wrote the first draft of the manuscript and all authors commented on previous versions of the manuscript. All authors read and approved the final manuscript.

\section{References}

1. Achi SC, Halami PM (2019) In Vitro Comparative Analysis of Probiotic and Functional Attributes of Indigenous Isolates of Bifidobacteria. Curr Microbiol 76:304-311. https://doi.org/10.1007/s00284018-1615-9

2. Archer AC, Halami PM (2015) Probiotic attributes of Lactobacillus fermentum isolated from human feces and dairy products. Appl Microbiol Biotechnol 99:8113-8123. https://doi.org/10.1007/s00253015-6679-x

3. Ayala FR, Bauman C, Bartolini M, et al (2017) Transcriptional regulation of adhesive properties of Bacillus subtilis to extracellular matrix proteins through the fibronectin-binding protein YloA. 104:804-821. https://doi.org/10.1111/mmi.13666

4. Azimirad M, Alebouyeh M, Naji T (2017) Inhibition of Lipopolysaccharide-Induced Interleukin 8 in Human Adenocarcinoma Cell Line HT-29 by Spore Probiotics: coagulans and B. subtilis (natto). Probiotics Antimicrob Proteins 9:56-63. https://doi.org/10.1007/s12602-016-9234-x

5. Baccigalupi L, Di A, Parlato M, et al (2005) Small surface-associated factors mediate adhesion of a food-isolated strain of Lactobacillus fermentum to Caco-2 cells. 156:830-836. https://doi.org/10.1016/j.resmic.2005.05.001

6. Bernet MF, Brassart D, Neeser JR, Servin AL (1994) Lactobacillus acidophilus LA 1 binds to cultured human intestinal cell lines and inhibits cell attachment and cell invasion by enterovirulent bacteria. Gut 35:483-489. https://doi.org/10.1136/gut.35.4.483

7. Bernet MF, Brassart D, Neeser JR, Servin AL (1993) Adhesion of human bifidobacterial strains to cultured human intestinal epithelial cells and inhibition of enteropathogen-cell interactions. Appl Environ Microbiol 59:4121-4128. https://doi.org/10.1128/aem.59.12.4121-4128.1993

8. Del Re B, Sgorbati B, Miglioli M, Palenzona D (2000) Adhesion, autoaggregation and hydrophobicity of 13 strains of Bifidobacterium longum. Lett Appl Microbiol 31:438-442. 
https://doi.org/10.1046/j.1365-2672.2000.00845.x

9. Duary RK, Rajput YS, Batish VK, Grover S (2011) Assessing the adhesion of putative indigenous probiotic lactobacilli to human colonic epithelial cells. 664-671. doi:10.4103/09715916.90992

10. Elshaghabee FMF, Rokana N, Gulhane RD, et al (2017) Bacillus as potential probiotics: Status, concerns, and future perspectives. Front Microbiol 8:1-15.

https://doi.org/10.3389/fmicb.2017.01490

11. Erdem L, Avelino F, Xicohtencatl-cortes J, Giro JA (2007) Host Protein Binding and Adhesive Properties of $\mathrm{H} 6$ and $\mathrm{H} 7$ Flagella of Attaching and Effacing Escherichia coli . 189:7426-7435. https://doi.org/10.1128/JB.00464-07

12. Fao J, Working WHO, Report G, et al (2002) Guidelines for the Evaluation of Probiotics in Food. 1-11

13. Gagnon M, Berner AZ, Chervet N, et al (2013) Comparison of the Caco-2, HT-29 and the mucussecreting HT29-MTX intestinal cell models to investigate Salmonella adhesion and invasion. J Microbiol Methods 94:274-279. https://doi.org/10.1016/j.mimet.2013.06.027

14. Hill C, Guarner F, Reid G, et al (2014) Expert consensus document: The international scientific association for probiotics and prebiotics consensus statement on the scope and appropriate use of the term probiotic. Nat Rev Gastroenterol Hepatol 11:506-514. https://doi.org/10.1038/nrgastro.2014.66

15. Hong HA, Huang JM, Khaneja R, et al (2008) The safety of Bacillus subtilis and Bacillus indicus as food probiotics. J Appl Microbiol 105:510-520. https://doi.org/10.1111/j.1365-2672.2008.03773.x

16. Inturri R, Molinaro A, Di Lorenzo F, et al (2017) Chemical and biological properties of the novel exopolysaccharide produced by a probiotic strain of Bifidobacterium longum. Carbohydr Polym 174:1172-1180. https://doi.org/10.1016/j.carbpol.2017.07.039

17. Ishibashi N, Yamazaki S (2001) Probiotics and safety. Am J Clin Nutr 73:465s-470s. https://doi.org/10.1093/ajcn/73.2.465s

18. Jacobsen CN, Nielsen VR, Hayford AE, et al (1999) Screening of probiotic activities of forty-seven strains of Lactobacillus by in vitro techniques and evaluation of the colonization ability of five selected strains in humans. Appl Environ Microbiol 65:4949-4956.

https://doi.org/10.1128/aem.65.11.4949-4956.1999

19. Johansson MEV, Phillipson M, Petersson J, et al (2008) The inner of the two Muc2 mucin-dependent mucus layers in colon is devoid of bacteria. Proc Natl Acad Sci U S A 105:15064-15069. https://doi.org/10.1073/pnas.0803124105

20. Juge N (2012) Microbial adhesins to gastrointestinal mucus. Trends Microbiol 20:30-39. https://doi.org/10.1016/j.tim.2011.10.001

21. Kerneis S, Bilge SS, Fourel V, et al (1991) Use of purified F1845 fimbrial adhesin to study localization and expression of receptors for diffusely adhering Escherichia coli during enterocytic differentiation of human colon carcinoma cell lines HT-29 and Caco-2 in culture. Infect Immun 59:4013-4018. https://doi.org/10.1128/iai.59.11.4013-4018.1991 
22. Kumar RS, Kanmani P, Yuvaraj N, et al (2011) Lactobacillus plantarum AS1 binds to cultured human intestinal cell line HT-29 and inhibits cell attachment by enterovirulent bacterium Vibrio parahaemolyticus. 481-487. https://doi.org/10.1111/j.1472-765X.2011.03136.x

23. Lee YK, Salminen S (1995) The coming of age of probiotics. Trends Food Sci Technol 6:241-245. https://doi.org/10.1016/S0924-2244(00)89085-8

24. Lindell G, Gilshenan K, Carlstedt I (2008) Four Modes of Adhesion are Used During Helicobacter pylori Binding to Human Mucins in the Oral and Gastric Niches. 81-93. https://doi.org/10.1111/j.1523-5378.2008.00587.x

25. Magalhães A, Reis CA, Magalhães A, Reis CA (2010) Helicobacter pylori adhesion to gastric epithelial cells is mediated by glycan receptors Helicobacter pylori adhesion to gastric epithelial cells is mediated by glycan receptors. 43:. https://doi.org/10.1590/S0100-879X2010007500049

26. Manjulata S, Kurrey NK, Halami PM (2018) In vitro anti-inflammatory activity among probiotic Lactobacillus species isolated from fermented foods. J Funct Foods 47:19-27. https://doi.org/10.1016/j.jff.2018.05.036

27. Marraffini LA, Dedent AC, Schneewind O (2006) Sortases and the Art of Anchoring Proteins to the Envelopes of Gram-Positive Bacteria. 70:192-221. https://doi.org/10.1128/MMBR.70.1.192

28. Neish AS (2009) Microbes in Gastrointestinal Health and Disease. Gastroenterology 136:65-80. https://doi.org/10.1053/j.gastro.2008.10.080

29. Ouwehand A, Vesterlund S (2003) Health aspects of probiotics. IDrugs 6:573-580. PMID:12811680

30. Palva A (2005) surface layers and their applications. 29:511-529. https://doi.org/10.1016/j.femsre.2005.04.003

31. Peng J Sen, Tsai WC, Chou CC (2001) Surface characteristics of Bacillus cereus and its adhesion to stainless steel. Int J Food Microbiol 65:105-111. https://doi.org/10.1016/S0168-1605(00)00517-1

32. Rani RP, Anandharaj M, Hema S, et al (2016) Purification of antilisterial peptide (Subtilosin A) from novel Bacillus tequilensis FR9 and demonstrate their pathogen invasion protection ability using human carcinoma cell line. Front Microbiol 7:1-15. https://doi.org/10.3389/fmicb.2016.01910

33. Romberger DJ (1997) Fibronectin. Int J Biochem Cell Biol 29:939-943. https://doi.org/10.1016/S1357-2725(96)00172-0

34. Roos S, Jonsson H (2002) A high-molecular-mass cell-surface protein from Lactobacillus reuteri 1063 adheres to mucus components. Microbiology 148:433-442.

https://doi.org/10.1099/00221287-148-2-433

35. Sánchez B, Arias S, Chaignepain S, et al (2009) Identification of surface proteins involved in the adhesion of a probiotic Bacillus cereus strain to mucin and fibronectin. Microbiology 155:17081716. https://doi.org/10.1099/mic.0.025288-0

36. Shobharani P, Halami PM (2014) Cellular fatty acid profile and H + -ATPase activity to assess acid tolerance of Bacillus sp . for potential probiotic functional attributes. 9045-9058. https://doi.org/10.1007/s00253-014-5981-3 
37. Swain MR, Anandharaj M, Ray RC, Parveen Rani R (2014) Fermented Fruits and Vegetables of Asia: A Potential Source of Probiotics. Biotechnol Res Int 2014:1-19. https://doi.org/10.1155/2014/250424

38. Tassell ML Van, Miller MJ (2011) Lactobacillus Adhesion to Mucus. 613-636. https://doi.org/10.3390/nu3050613

39. Van Klinken BJW, Dekker J, Buller HA, Einerhand AWC (1995) Mucin gene structure and expression: Protection vs. adhesion. Am J Physiol - Gastrointest Liver Physiol 269: https://doi.org/10.1152/ajpgi.1995.269.5.g613

40. Xi T, Chen YM, Zheng Y, et al (2009) In vitro cytotoxicity of bacterial cellulose scaffolds used for tissue-engineered bone. J Bioact Compat Polym 24:137-145. https://doi.org/10.1177/0883911509102710

\section{Figures}
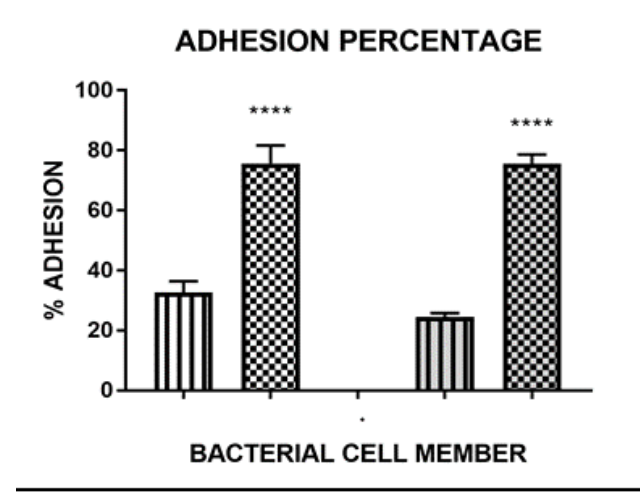

$$
\text { 흥 }
$$

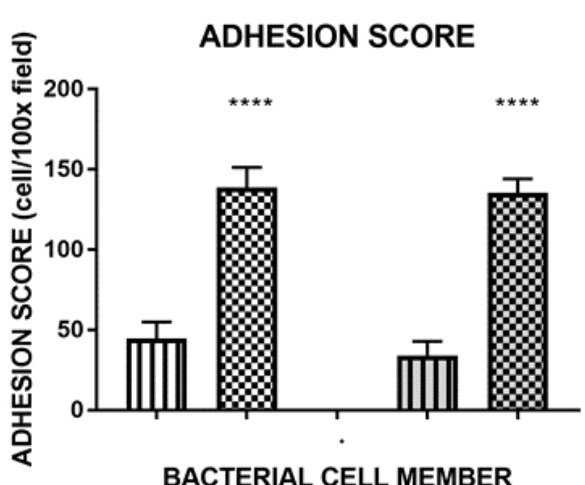

Q8 B. licheniformis III Bif. breve
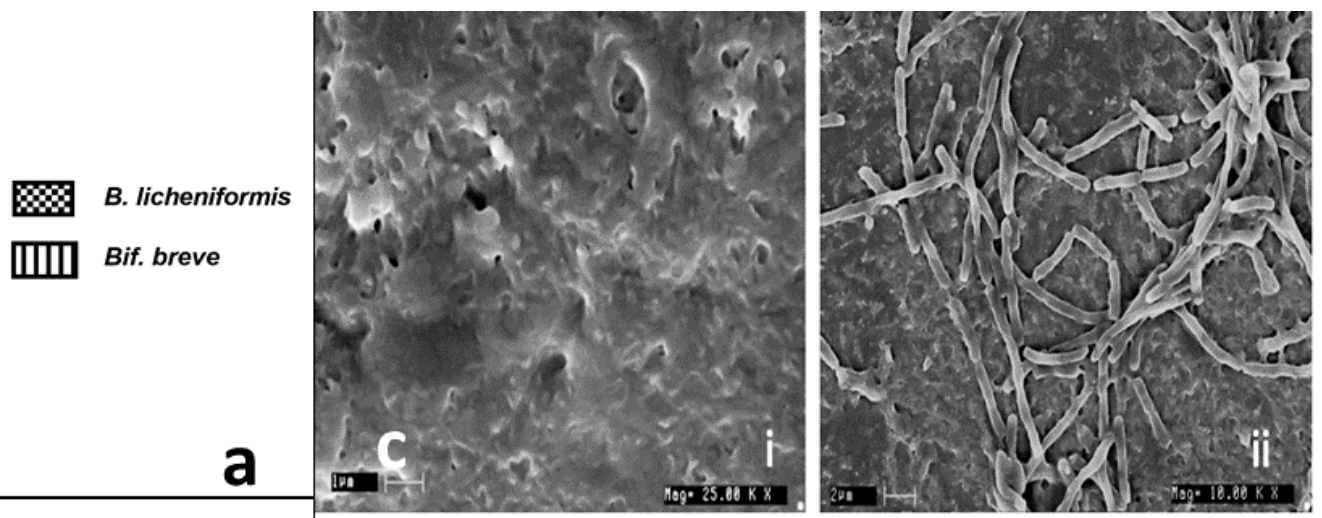

BACTERIAL CELL MEMBER
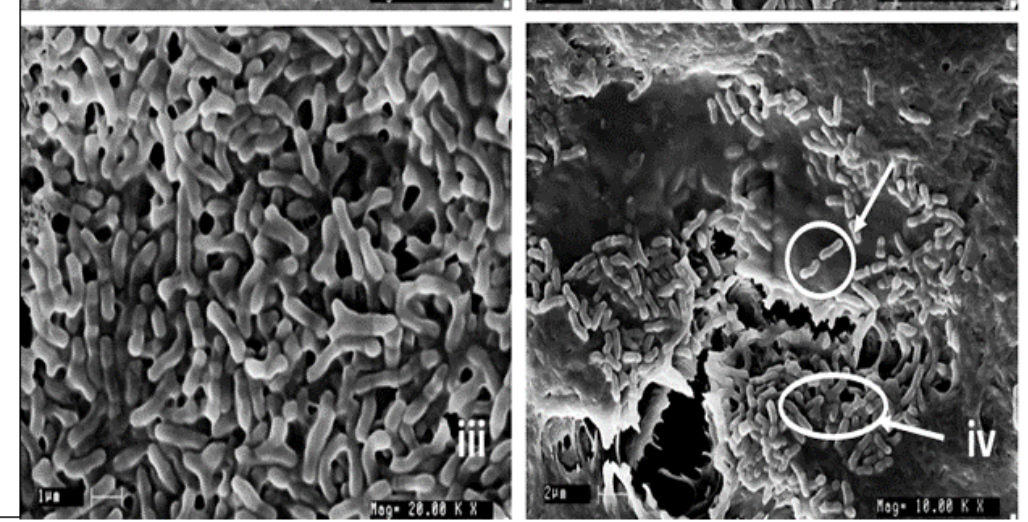

\section{Figure 1}

Binding efficiency of probiotic bacteria on HT-29 cell lines. a: Adhesion score of B. licheniformis and Bif. breve on HT-29 cell line. The values presented are the mean $\pm S D(n=20)$. P-value $<0.05(\star \star \star \star=<0.0001)$, b: Adhesion percentage of B. licheniformis and Bif. breve on HT-29 cell line. The values presented are the mean $\pm S D(n=3)$. P-value $<0.05(* \star \star *=<0.0001)$, c: Scanning electron microscopic study of bacterial adhesion on HT-29 cell line (i: untreated cell, ii: B. licheniformis, iii: Bif. breve, iv: B. licheniformis and Bif. breve \{upper circle indicates B. licheniformis and the lower circle indicates Bif. breve $\}$ ). Magnification $=a$, c: $20.00 \mathrm{KX} ; \mathrm{b}, \mathrm{d}: 10.00 \mathrm{KX}$ 


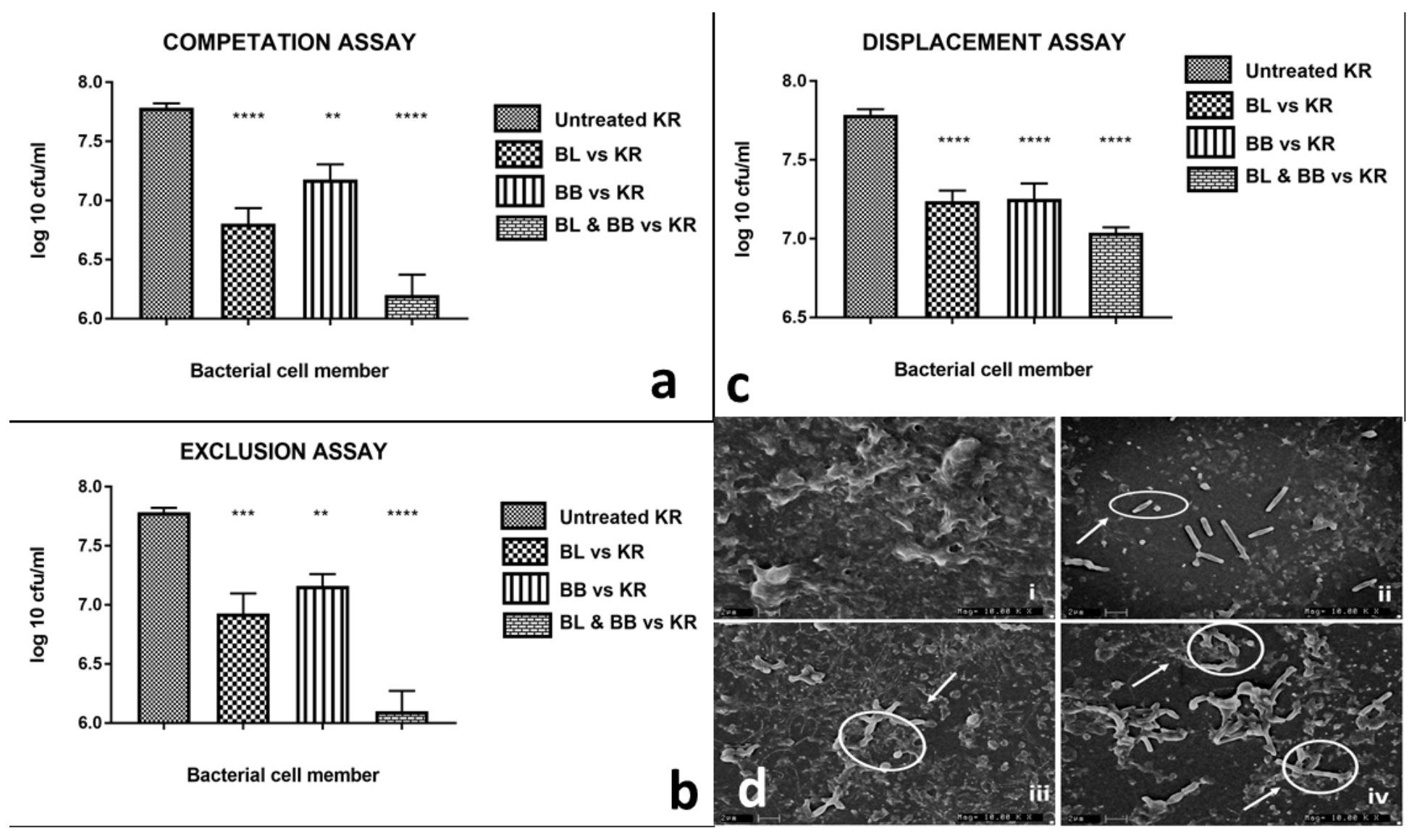

Figure 2

Invasion assay against K. rhizophila a: Competition assay, b: Exclusion assay, c: Displacement assay, d: Scanning Microscopic analysis of invasion assay on HT-29 cell line (i: untreated cell line, ii: B. licheniformis against K. rhizophila, iii: Bif. breve against K. rhizophila, iv: B. licheniformis and Bif. breve against $\mathrm{K}$. rhizophila) encircled in image $\mathrm{d}(\mathrm{ii})$ indicates the combination of $\mathrm{B}$. licheniformis and $\mathrm{K}$. rhizophila, encircled in image d(iii) indicates the combination of Bif. breve and K. rhizophila, $d(i v)$ indicate the combination of B. licheniformis, Bif. breve and K. rhizophila. Abbr. ML: K. rhizophila, BL: B. licheniformis, BB: Bif. breve). The values presented are the mean $\pm S D(n=3)$. P-value $=<0.05$. $(* \star \star \star=$ $<0.0001, * \star *=0.0001, * *=0.0012$ ). Magnification: $10.00 \mathrm{KX}$ 


\section{CYTOTOXICITY ASSAY}

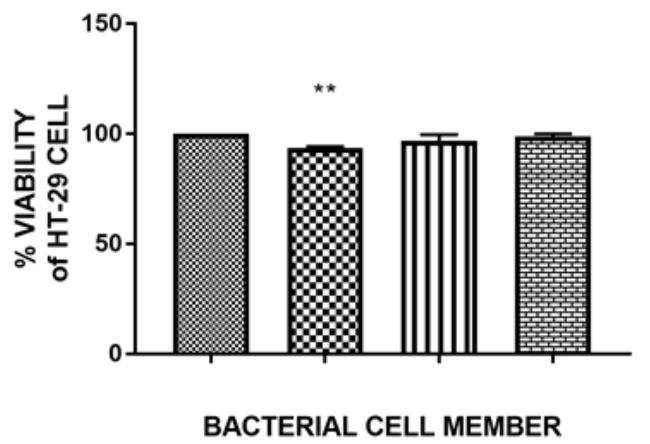

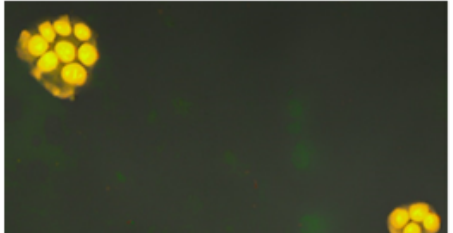

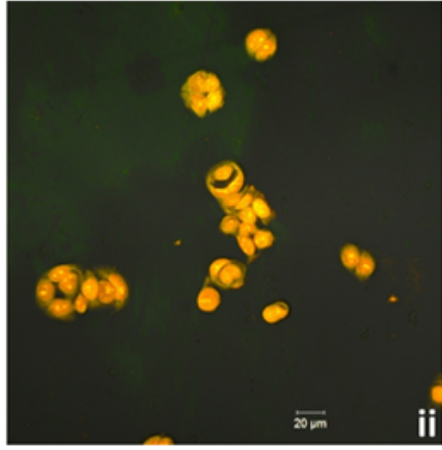

III Bif. breve

宦埾 B. licheniformis \& Bif. breve
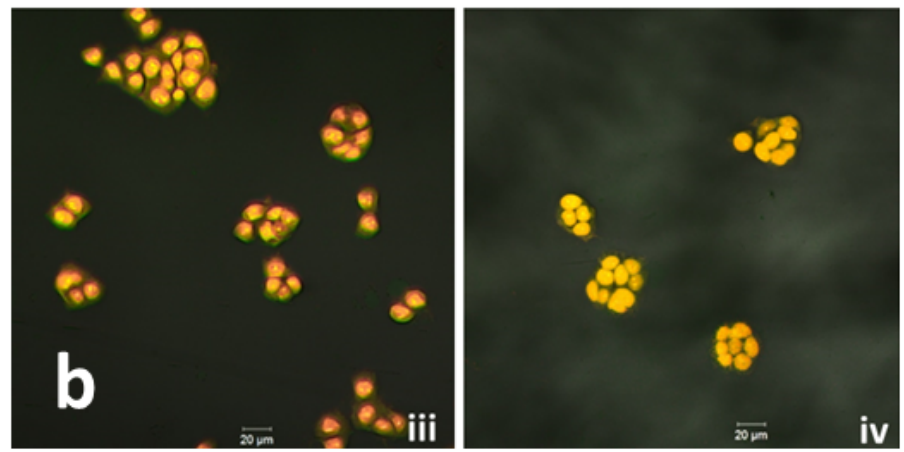

\section{Figure 3}

a: Cytotoxicity assay on HT-29 using MTT method using B. licheniformis and B. breve. The values presented are the mean \pm SD $(n=3)$ P-value $=<0.05$. b: Confocal microscopic observation for the HT-29 cell viability (i: untreated, ii: B. licheniformis, iii: Bif. breve, iv: B. licheniformis and Bif. breve) Magnification: $10 \mu \mathrm{M}$. 